\title{
EFFECT OF FEEDING RATE AND FREQUENCYON GROWTH PERFORMANCE, SEX CONVERSION RATIO AND PROFITABILITY OF NILE TILAPIA (OREOCHROMIS NILOTICUS) FRY IN HAPA AT COMMERCIAL HATCHERIES
}

\author{
R.M. Abou Zied ${ }^{1}$ and A.A.A. Ali ${ }^{2}$ \\ ${ }^{1}$ Faculty of Agriculture, Fayoum University, Egypt. \\ ${ }^{2}$ Central Laboratory for Fisheries Research, Abbasa, Agricultural Research Center, Ministry of \\ Agriculture, Egypt.
}

\section{SUMMARY}

\begin{abstract}
$\mathrm{T}$ This trial was conducted for twenty one days to evaluate the efficacy of feeding rate and frequency on growth performance, sex conversion ratio and profitability of monosex tilapia (Oreochromis niloticus) fry followed by a 45 days feeding trial to determine sex conversion ratio. A total of 360000 fry of three days- old (weight $10.99 \pm 0.01 \mathrm{mg}$ in average) were stocked in twelve hapa $(2 \times 4 \times 1 \mathrm{~m})$ at the rate of 30000 fry/hapa. The hapas were divided into six treatments on the basis of feeding rates and frequencies viz. changeable rates 30>20>10 and 4 times/day (T1), rate 30>20>10 and 6 times/day (T2), constant rate $20 \%$ for 4 times/day (T3), rate $20 \%$ for 6 times/day (T4), rate $15 \%$ for 4 times/day (T5) and rate $15 \%$ for 6 times/day (T6) having two replications. Fry were fed mixed feed with $17 \alpha$-methyltestosterone (MT) hormone at a rate of $100 \mathrm{mg} / \mathrm{kg}$ diet and supplemented with mixture of vitamin $\mathrm{C}$ and selenium. The water quality parameters were within suitable ranges for proper growth of $O$. niloticus. After ending the trial period, significant variations $(\mathrm{P} \leq 0.05)$ were observed in six treatments and $\mathrm{T} 2$ showed the best performance in case of all parameters studied such as final weight, weight gain, feed conversion ratio, specific growth rate, sex conversion ratio and profitability. The lowest values were obtained with T5 (feeding rate $15 \%$ and 4 times/day).
\end{abstract}

Keywords: Nile tilapia, feeding rate, feeding frequency, specific growth rate, profit index and sex reversal.

\section{INTRODUCTION}

Reduced production costs and maintaining the quality of sex conversion ratio considered to be the most important priorities of hatcheries

Sexual dimorphism is a significant factor in Oreochromis niloticus where males grow significantly faster, larger and more uniform in size than females (Manosroi et al., 2004; Bwanika et al. 2007 and Mensah et al. 2013). Although tilapias in general are known for their aquaculture potential but their growth and other production traits are largely influenced by genetics (Ajiboye and Yakubu 2010). Early sexual maturity of this species is a well-recognized problem. Use of monosex (all-male) has been widely, if inconsistently, promoted and adopted (Green et al., 1997).

Synthetic androgens are used in fish culture as sex controlling agents and as growth promoters if energy is shut away from developing ovaries towards growth of somatic tissues (Rizkalla et al., 2004). The more common method of generating mostly male populations is through the use of steroids fed to sexually undifferentiated fry, when the newly hatched tilapias are still developing their gonads. Even though they are determined genotypically, their phenotype or morphological characteristics can still be altered. By exposing the fish to forms of testosterone or estrogen, the gonad can switch (Al-Hakim et al., 2012).

Although monosex male population can be obtained by direct or indirect methods, oral administration of Oreochromis niloticus has been reported to be the most preferred method in commercial uses (Green and Teichert-Coddington, 2000; Wahby and Shalaby, 2010; Celik et al., 2011). 17 $\alpha$-methyltestosterone $(17 \alpha-\mathrm{MT})$ is a synthetic male hormone which closely mimics the naturally-produced hormone testosterone. The most common sex-reversal treatment involves giving a powdered fish feed to the firstfeeding (and still sexually undifferentiated) tilapia fry and diet contains 60-100 mg 17a-MT/kg of feed until the 28th days post hatching (Al-Hakim et al., 2012). 
The relationship between rate of feeding and rate of conversion is very important in fish culture when fish are fed insufficiently or excessively, their growth or feed efficiency may decrease, resulting in increasing production costs and water quality deterioration (Winnie 2012). If fish are fed at too high rate, much of the food is wasted, and, even though growth may be excellent, the cost of production is excessive. Further, in some cases uneaten food decaying in the water may be detrimental to fish growth. If the feeding rate is too low, approaching the rate required for maintenance, growth is very slow, and the rate of conversion is very high (Shell 1996). Increased feeding frequencies decrease aggressive behavior in some fish species, these results in faster growth and less size variation. However, there is a limit to the frequency that will result in benefits. Because of their rapid growth, high energy requirements, and small stomachs, fry require frequent feeding. Fry should be fed as many as 8-10 times a day (Riche and Girling 2003). Thus the diet amount fed each time, or feeding frequency, may influence diet utilization. This is due to the fact that diet is directly applied to water and the non-untaken portion will be dissolved and lixiviated. Feed conversion ratio increase and environmental pollution are the results.

Since that the main aim is that fries uptake a high daily diet ratio to meet their nutrition requirements and thus ingest adequate hormonal amounts, and since that the high feeding frequency results in high daily diet intake ratio and small amounts of diet per feeding (Meer et al., 1997), a higher frequency may be the most adequate, particularly in the sex reversal period of tilapia larvae culture. There are a wide variation in opinions about feeding frequency diverge from 2 times a day, as used by Guerrero (1975) pioneer experiments, 2 to 4 times a day as recommended by Popma and Green (1990), three times a day as used by Alcazar (1988), four times a day as used by Phelps et al. (1995) and by Vera Cruz and Mair (1994), 6 to 8 times a day as reported by Carberry and Hanley (1997), up to the minimum of 8 times a day as recommended by Lim (1997). With regard to the economic aspect, a higher feeding frequency would only be justified when absolutely necessary for a better performance. Needless to say, a higher feeding frequency would require higher costs with salary or with automatic feeders. Taking into account the above biological and economic aspects of sex reverted tilapia fries production, the aim of this experiment was to verify the minimal feeding frequency required for an optimal performance in that period.

The aim of this work was to investigate the effect of fry feeding rate and frequency on growth performance, sex reversaland profitability of $O$. niloticus fry in hapa pond system at commercial hatcheries.

\section{MATERIALS AND METHODS}

This study was conducted in a greenhouses commercial hatchery at Edko province, Beheira Governorate, Egypt to evaluate the effect of feeding rate and frequency on growth performance, sex conversion ratio and profitability of Nile tilapia fry. The experiment began in 15/03/2015 and lasted for 21 days (basic trials) followed by a 45 days feeding experiment to determine sex conversion ratio.

Three hundred and sixty thousand fry (yolk sac) were equally divided on twelve hapa located in fry earthen pond. Each hapa has an area of $2 \times 4 \mathrm{~m}$ with a water depth of $80-85 \mathrm{~cm}$. fry stocked at a rate of $5000 / \mathrm{m}^{3}$ with an average weight of $10.99 \pm 0.01 \mathrm{mg} /$ fry.

The first replicate of all treatments started in a day and the second replicate was started in the second day because the hatchery production of fry was not enough to supply enough fries to start all treatments in the same day

Diets: fries in Hapas were fed on a diet that contained $53 \%$ protein $(80 \%$ fish meal herring mixed with $20 \%$ flour ) with $17 \alpha$ methyl testosterone at a rate of $100 \mathrm{mg} / \mathrm{kg} \operatorname{diet}($ Al-Hakim et al., 2012) and supplemented with mixture of vitamin $\mathrm{C}$ and selenium. Feed was offered at hours 8.0, 11.0, 14.0, and 17.0 for treatment 4times/day and at hour 8.0, 10.0, 12.0, 14.0, 16.0 and 18.0 for treatment 6times/day as follows:

$-\mathrm{T}_{1}$ feed fries at changeable feeding rate $30 \%$ of body weight in first week then decreased to $20 \%$ in the second week and $10 \%$ in the third week 4 times/day.

$-\mathrm{T}_{2}$ feed fries at changeable feeding rate $30 \%$ of body weight in first week then decreased to $20 \%$ in the second week and $10 \%$ in the third week 6 times/day.

$-\mathrm{T}_{3}$ feed fries at constant feeding rate $20 \%$ of body weight for 21 days 4 times/day.

$-\mathrm{T}_{4}$ feed fries at constant feeding rate $20 \%$ of body weight for 21 days 6 times/day.

$-\mathrm{T}_{5}$ feed fries at constant feeding rate $15 \%$ of body weight for 21 days 4 times/day.

$-\mathrm{T}_{6}$ feed fries at constant feeding rate $15 \%$ of body weight for 21 days 6 times/day. 


\section{Determination of sex conversion:}

At the end of the experiment, five hundred fries from each treatment were confined in small hapa $(1 \times$ $2 \mathrm{~m}$ ) and fed for 45 days until fry weight reached 4-5 g on artificial diet containing $30 \%$ CP to determine sex conversion ratio. The identification of the phenotypic sex for 200 juvenile fry from each treatment was determined by microscopic examination of the gonads. The thin gonad (thread-like structure lies along the dorsal side of the abdominal cavity) was extracted very carefully, placed on a glass slide and stained with a drop of aceto-carmine stain then it was lightly squashed with a glass cover slip and examined at $10 \mathrm{X}$ magnification for the identification of the juvenile gonads. The fish was a presumptive male and female if densely packed oocytes were found as reported by Guerrero and Shelton (1974).

Water temperature, $\mathrm{pH}$, dissolved oxygen $\left(\mathrm{DO}_{2}\right)$, ammonia $\left(\mathrm{NH}_{3}-\mathrm{N}\right)$, nitrate and salinity throughout the experimental period were measured periodically in the morning and at noon by centigrade thermometer, Orion digital $\mathrm{pH}$ meter model 201, oxygen meter, Cole Parmer model 5946, HACH test kit ammonia mid-range 0-3 mg/L model NI-8 , HACH test kit Nitrate/Nitrite model NI-12 and TDS apparatus, respectively.

\section{Parameters:}

At the end of the experiment, growth parameters and survival rate were measured as follows:

- Weight gain = Final weight - Initial weight (Effiong et al., 2009).

- Daily gain = Weight gain, g /period in days. (Effiong et al., 2009).

- Specific growth rate $($ SGR, \%) = 100 (ln Final weight-ln Initial weight)/period in days, where $\ln$ is the natural log. (Effiong et al., 2009).

- Feed conversion ratio $(\boldsymbol{F C R})=$ feed offered / weight gain $\quad$ (Effiong et al., 2009).

- Survival rate (SR) \%= Final number of fish /Initial number of fish x 100.(Charo-Karisa et al., 2006)

\section{Economic analysis}

A simple economic analysis was used to assess the cost effectiveness of diets used in the feed trial. The cost of feed was calculated using market prices, taking into consideration the cost of feed and the transport fare with the assumption that all other operating costs remained constant (e.g. cost of constructing hapa, cost of fingerlings and labor). Indices for economic evaluation included:

(i) Incidence cost (IC), which was calculated as:

$\mathrm{IC}=$ Cost of feed/ No. of fry produced

IC is actually the cost of feed to produce 1000 fry (relative cost per unit), and the lower the value, the more profitable using that particular feed (Nwanna, 2003; Abu et al., 2010)

(ii) Profit index (PI), which was calculated as:

PI = value of fish produced/ Cost of feed

\section{Statistical Analysis:}

Data were statistically analyzed using a one-way analysis of variance using SPSS version 16 (2007). Mean of treatments were compared by Duncan Multiple Range Test (1955) when the differences were significant.

\section{RESULTS AND DISCUSSION}

\section{Water quality parameters:}

Water quality parameters were measured during the study in fish hapas. Mean values of water quality parameters were recorded as follows: dissolved oxygen (DO) $5.8 \pm 0.13 \mathrm{mg} / \mathrm{L}, \mathrm{pH} 8.12 \pm 0.14$, temperature $29 \pm 1.0{ }^{\circ} \mathrm{C}, \mathrm{NH}_{3}-\mathrm{N} 0.4 \pm 0.15 \mathrm{mg} / \mathrm{L}$ and salinity $2.6 \pm 0.18 \%$ o respectively. These values are within the safe ranges and acceptable for the spawning and growth of tilapia as reported by El-Sayed (2006), Magid and Babiker (1975), Ross (2000) and El-Sherif and El-Feky (2008).

Effect of feeding rate on growth performance of Nile tilapia fry: 
Table (1) illustrated that the feeding rate significantly $(\mathrm{P} \leq 0.05)$ affected the growth performance parameters, final weight (FW), weight gain (WG), daily gain (DG), specific growth rate (SGR) and feed conversion ratio (FCR). The treatment group which received $20 \%$ feeding rate showed the best final weight $(162.93 \mathrm{mg})$, weight gain $(151.95 \mathrm{mg})$, daily gain $(7.23 \mathrm{mg})$ and SGR (12.84) followed by the treatment group received changeable feeding rate 30>20>10 which were 145.39, 134.41, 6.04 and 12.29 for $\mathrm{FW}, \mathrm{WG}$, DG and SGR respectively and these parameters are insignificant $(\mathrm{P} \geq 0.05)$ between changeable feeding $30>20>10$ and constant feeding rate $15 \%$.

Table (1). Effect of feeding rate on growth performance of Nile tilapia fry during sex reversal

\begin{tabular}{lccccccc}
\hline $\begin{array}{c}\text { Feeding } \\
\text { rate }\end{array}$ & $\begin{array}{c}\text { Initial } \\
\text { weight, mg }\end{array}$ & $\begin{array}{c}\text { Final } \\
\text { weight, mg }\end{array}$ & $\begin{array}{c}\text { Weight } \\
\text { gain, mg }\end{array}$ & $\begin{array}{c}\text { Daily } \\
\text { gain, mg }\end{array}$ & SGR, \% & $\begin{array}{c}\text { Survival } \\
\text { rate, \% }\end{array}$ & FCR \\
\hline $30>20>10$ & 10.98 & $145.39^{\mathrm{b}}$ & $134.41^{\mathrm{b}}$ & $6.40^{\mathrm{b}}$ & $12.29^{\mathrm{b}}$ & $90.87^{\mathrm{a}}$ & $1.18^{\mathrm{b}}$ \\
20 & 10.98 & $162.93^{\mathrm{a}}$ & $151.95^{\mathrm{a}}$ & $7.23^{\mathrm{a}}$ & $12.84^{\mathrm{a}}$ & $90.28^{\mathrm{a}}$ & $1.46^{\mathrm{a}}$ \\
15 & 10.99 & $139.49^{\mathrm{b}}$ & $128.50^{\mathrm{b}}$ & $6.12^{\mathrm{b}}$ & $12.10^{\mathrm{b}}$ & $80.95^{\mathrm{b}}$ & $1.45^{\mathrm{a}}$ \\
SED & 0.01 & 5.39 & 5.39 & 0.26 & 0.17 & 2.51 & 0.08 \\
\hline
\end{tabular}

* Average in the same column having different superscripts significantly different at $(P \leq 0.05)$.

$* * S E D$, standard error of a difference between 2 means $=\sqrt{ }(2 \times$ Error $M S / r)$

Survival rate and FCR values showed a significant differences $(\mathrm{P} \leq 0.05)$ between feeding rate treatment group. The results may be due to the large quantity of feed offered to fry in the first week of feeding with changeable feeding 30>20>10 and 20\% feeding rate these lead to fry consumed more feed than that of feeding rate $15 \%$ which were low quantity of feed and large, strong fry consumed feed only, but the weak fry don't crowded resulting increased mortality and lowest growth of fries feeding $15 \%$.

The poor FCR noticed with feeding rate $20 \%$ may be attributed to the presence of more feed than fry requirements specially in the third week but changeable feeding 30>20>10 during sex reversal period at $30 \%$ in the first week then decreased to $10 \%$ in the third week improved FCR due to the low quantity of feed. These results are in agreement with the results obtained by Santiago et al. (1987) and El-Sayed (2002) who reported that fish growth rates and survival were extremely poor at $10 \%$ feeding level, and improved significantly with increasing feeding levels up to $30 \%$, and levelled off with further increase in feeding levels.

\section{Effect of feeding rate on sex conversion ratio and profitability of Nile tilapia fry}

The effect of feeding rate on sex conversion ratio showed a significant $(\mathrm{P} \leq 0.05)$ differences between feeding rates and the best sex conversion ratio obtained with changeable feeding rates 30>20>10 (96.75\% male) and feeding 20\% (95.75\% male) but the feeding rate 15\% resulted the lowest male \% (93\%) (Table 2 ). The results may be explained on the basis that changeable feeding rate and $20 \%$ feeding rate provides a large quantity of feed offered to fry specially in the first week which sex conversion happed compared to the small quantity offered by the $15 \%$ feeding rate, the larger tilapia dominate the area around the feeder and consume most of the feed, resulting in considerable size variation and often poor sex reversal. Pandian and Varadaraj (1987), Phelps and Popma (2000) distained similar results on poor sex reversal suing similar feeding rate.

The calculation of profitability showed that the treatment group that received changeable feeding rate $30>20>10$ was more profitability than the other two treatment groups. The results of this particular work recommended the use of changeable feeding rate to get the highest profit index (9.92) and highest male percent (96.75).

Table (2). Effect of feeding rate on sex reversal and profitability of Nile tilapia fry

\begin{tabular}{lcccccc}
\hline $\begin{array}{c}\text { Feeding rate, } \\
\%\end{array}$ & Male, $\%$ & $\begin{array}{c}\text { Feed } \\
\text { offered }\end{array}$ & Feed cost & $\begin{array}{c}\text { Fry No } \\
\text { sales }(\mathrm{V})\end{array}$ & $\begin{array}{c}\text { Values of } \\
\text { fry sales }\end{array}$ & Profit index \\
\hline $30>20>10$ & $96.75^{\mathrm{a}}$ & $4478.75^{\mathrm{c}}$ & $72.11^{\mathrm{c}}$ & $28625^{\mathrm{a}}$ & $716^{\mathrm{a}}$ & $9.92^{\mathrm{a}}$ \\
20 & $95.75^{\mathrm{a}}$ & $6227.50^{\mathrm{a}}$ & $100.26^{\mathrm{a}}$ & $28438^{\mathrm{a}}$ & $711^{\mathrm{a}}$ & $7.09^{\mathrm{c}}$ \\
15 & $93.00^{\mathrm{b}}$ & $4645.00^{\mathrm{b}}$ & $74.78^{\mathrm{b}}$ & $25500^{\mathrm{b}}$ & $638^{\mathrm{b}}$ & $8.53^{\mathrm{b}}$ \\
SED & 0.62 & 29.80 & $0.48^{2}$ & 790 & 19.74 & 0.27 \\
\hline
\end{tabular}

* Average in the same column having different superscripts significantly different at $(P \leq 0.05)$.

$* * S E D$, standard error of a difference between 2 means $=\sqrt{ }(2 \times$ Error MS $/ r)$ 


\section{Effect of feeding frequency on growth performance of Nile tilapia fry:}

Results in Table (3) revealed that the growth performance was insignificantly ( $\mathrm{P} \geq 0.05)$ affected in all parameters such as final weight, weight gain, daily gain, specific growth rate and feed conversion ratio. The results take a constant trend with feeding frequency 4 or 6 times/day and the best with feeding frequency 6 times/day. These results are in agreement with that obtained by Ferdous et al. (2014), Luthada and Jerling (2013), Pouomogne and Ombredane (2001) and Sanches and Hayashi (2001).

Table (3). Effect of feed frequency on growth performance and profit index of Nile tilapia fry

\begin{tabular}{cccccccc}
\hline $\begin{array}{c}\text { Feed } \\
\text { frequency }\end{array}$ & $\begin{array}{c}\text { Initial } \\
\text { weight }\end{array}$ & $\begin{array}{c}\text { Final } \\
\text { weight }\end{array}$ & $\begin{array}{c}\text { Weight } \\
\text { gain }\end{array}$ & SGR & $\begin{array}{c}\text { Survival } \\
\text { rate }\end{array}$ & FCR & Profit index \\
\hline 4 & 10.99 & 146.14 & 135.15 & 12.31 & 85.85 & 1.40 & 8.35 \\
6 & 10.99 & 152.39 & 141.40 & 12.51 & 88.89 & 1.29 & 8.68 \\
SED & 0.011 & 11.55 & 11.56 & 0.36 & 5.26 & 0.14 & 1.28 \\
\hline$* *$ SED standard error of a difference between 2 means $=\sqrt{ }(2 \times$ Error $M S / r)$ & &
\end{tabular}

** SED, standard error of a difference between 2 means $=\sqrt{ }(2 \times$ Error $M S / r)$

\section{Effect of feeding rate and frequency on growth performance of Nile tilapia fry:}

Table (4) showed that the growth performance was significantly $(\mathrm{P} \leq 0.05)$ affected in all parameters such as final weight, weight gain, daily gain, specific growth rate and feed conversion ratio. The results obtained with feeding rate $20 \%$ and feeding 6 times/day showed the best final weight (166.73 mg), weight gain $(155.74 \mathrm{mg})$, daily gain $(7.42 \mathrm{mg})$ and SGR (12.95) and the lowest values were recorded with $15 \%$ feeding rate and 4 times/day, but survival rate and FCR were the best with changeable feeding rate at 6 times/day (92.06 and 1.13) than the other treatments. The lowest values were obtained with $15 \%$ feeding rate and 4 times/day. The results of this particular work are clearly supported by the findings of Ferdous et al. 2014 and Pouomogne and Ombredane. 2001 who stated that, increasing the frequency of feeding in tilapia fry positively correlated with better fishgrowth performance. Also, Luthada and Jerling (2013) showed that weight gain, SGR and FCR of $O$. mossambicus fry are significantly affected by feeding frequency. High weight gain and specific growth rate at higher feeding frequencies have also been reported for red tilapia hybrid fry by Siraj et al., (1988) and juvenile O. niloticus Riche et al.( 2004).

Sena and Trevor (1995) suggested that the manual feeding frequency severaltimes per day is the most appropriate for intensive grown tilapia. Tung and Shiau (1991) also confirmed that weight gain of $O$. niloticus increased with increasing feeding frequency.

Table (4). Effect of feeding rateand frequency on growth performance of Nile tilapia fry

\begin{tabular}{lccccccc}
\hline Treatment & $\begin{array}{c}\text { Initial } \\
\text { weight }\end{array}$ & $\begin{array}{c}\text { Final } \\
\text { weight }\end{array}$ & $\begin{array}{c}\text { Weight } \\
\text { gain }\end{array}$ & $\begin{array}{c}\text { Daily } \\
\text { gain }\end{array}$ & SGR & $\begin{array}{c}\text { Survival } \\
\text { rate }\end{array}$ & FCR \\
\hline 1 & 10.99 & $143.17^{\mathrm{c}}$ & $132.18^{\mathrm{c}}$ & $6.29^{\mathrm{c}}$ & $12.22^{\mathrm{c}}$ & $89.68^{\mathrm{a}}$ & $1.20^{\mathrm{c}}$ \\
2 & 10.99 & $147.62^{\mathrm{bc}}$ & $136.63^{\mathrm{bc}}$ & $6.51^{\mathrm{bc}}$ & $12.37^{\mathrm{bc}}$ & $92.06^{\mathrm{a}}$ & $1.13^{\mathrm{c}}$ \\
3 & 10.99 & $159.13^{\mathrm{ab}}$ & $148.14^{\mathrm{ab}}$ & $7.05^{\mathrm{ab}}$ & $12.73^{\mathrm{bc}}$ & $89.29^{\mathrm{a}}$ & $1.49^{\mathrm{a}}$ \\
4 & 10.99 & $166.73^{\mathrm{a}}$ & $155.74^{\mathrm{a}}$ & $7.42^{\mathrm{a}}$ & $12.95^{\mathrm{a}}$ & $91.27^{\mathrm{a}}$ & $1.40^{\mathrm{b}}$ \\
5 & 10.99 & $136.14^{\mathrm{c}}$ & $125.15^{\mathrm{c}}$ & $5.96^{\mathrm{c}}$ & $11.98^{\mathrm{c}}$ & $78.57^{\mathrm{b}}$ & $1.51^{\mathrm{a}}$ \\
6 & 10.99 & $142.83^{\mathrm{c}}$ & $131.84^{\mathrm{c}}$ & $6.28^{\mathrm{c}}$ & $12.21^{\mathrm{c}}$ & $83.33^{\mathrm{b}}$ & $1.34^{\mathrm{b}}$ \\
SED & 0.01 & 4.81 & 4.81 & 0.23 & 0.15 & 2.00 & 0.03 \\
\hline
\end{tabular}

* Average in the same column having different superscripts significantly different at $(P \leq 0.05)$.

$* * S E D$, standard error of a difference between 2 means $=\sqrt{ }(2 \times$ Error MS/r $)$

\section{Effect of feeding rate and frequency on sex conversion ratio and profitability of Nile tilapia fry}

The results of feeding rate and frequency on sex conversion ratio (Table 5) showed a significant $(\mathrm{P} \leq 0.05)$ differences between treatments and the best sex conversion ratio obtained with changeable feeding 30>20>10 and feeding 6 times/day while the feeding rate 15\% and feeding 4 times /day recorded the lowest male $\%$. The results may be due to a large quantity of feed offered to fry specially in the first week which sex conversion, take place, compared to rate $15 \%$ and 4 times/day which weak fry don't consume enough feed resulting poor sex reversal $(92 \%)$. When small quantities of feed are released uniformly throughout the day, the larger tilapia dominate the area around the feeder and consume most of the feed, resulting in considerable size variation and often poor sex reversal. 
Table (5). Effect of feeding rate and frequency onsex reversal andprofitability of Nile tilapia fry

\begin{tabular}{lcccccc}
\hline Treatment & Male, \% & $\begin{array}{c}\text { Feed } \\
\text { offered, g }\end{array}$ & Feed cost & $\begin{array}{c}\text { Fry No } \\
\text { sales (V) }\end{array}$ & $\begin{array}{c}\text { Values of } \\
\text { fry sales }\end{array}$ & Profit index \\
\hline 1 & $96.50^{\mathrm{ab}}$ & $4487.50^{\mathrm{c}}$ & $72.25^{\mathrm{c}}$ & $28250^{\mathrm{a}}$ & $706.25^{\mathrm{a}}$ & $9.77^{\mathrm{a}}$ \\
2 & $97.00^{\mathrm{a}}$ & $4470.00^{\mathrm{c}}$ & $71.97^{\mathrm{c}}$ & $29000^{\mathrm{a}}$ & $725.00^{\mathrm{a}}$ & $10.07^{\mathrm{a}}$ \\
3 & $95.00^{\mathrm{b}}$ & $6210.00^{\mathrm{a}}$ & $99.98^{\mathrm{a}}$ & $28125^{\mathrm{a}}$ & $703.13^{\mathrm{a}}$ & $7.03^{\mathrm{d}}$ \\
4 & $96.00^{\mathrm{ab}}$ & $6245.00^{\mathrm{a}}$ & $100.54^{\mathrm{a}}$ & $28750^{\mathrm{a}}$ & $718.75^{\mathrm{a}}$ & $7.15^{\mathrm{d}}$ \\
5 & $92.50^{\mathrm{c}}$ & $4665.00^{\mathrm{b}}$ & $75.11^{\mathrm{b}}$ & $24750^{\mathrm{b}}$ & $618.75^{\mathrm{b}}$ & $8.24^{\mathrm{c}}$ \\
6 & $93.50^{\mathrm{c}}$ & $4625.00^{\mathrm{b}}$ & $74.46^{\mathrm{b}}$ & $26250^{\mathrm{b}}$ & $656.25^{\mathrm{b}}$ & $8.81^{\mathrm{b}}$ \\
SED & 0.58 & 28.47 & 0.46 & 633.28 & 15.83 & 0.20 \\
\hline
\end{tabular}

* Average in the same column having different superscripts significantly different at $(P \leq 0.05)$.

** SED, standard error of a difference between 2 means $=\sqrt{ }(2 \times$ Error MS/r $)$

Regarding the profitability of hatchery changeable feeding 30>20>10 with feeding 6 times/day was the best than other treatment. The results of this research work revealed that changeable feeding 30>20>10 with feeding 6 times/day produced best male \% (97) and profit index (10.07) followed by changeable feeding 30>20>10 with feeding 4 times/day produced male \% (96.50) and profit index was (9.77) but the lowest male \% with feeding rate $15 \%$ with feeding 4 times/day.

\section{CONCLUSION}

The first days after hatching are crucial in the process of sex reversal. Diets containing $17 \alpha-$ methyltestosterone hormone should be given in sufficient quantity. The optimal feeding rate and frequency can lead to maximization of profit. In this particular study it was found that changeable feeding rate $30>20>10$ with a frequency of 6 times / day was the proper.

\section{REFERENCES}

Abu, O.M.G.; L.O. Sanni; E.S. Erondu; O.A. Akinrotimi (2010). Economic viability of replacing maize with whole cassava root meal in the diet of Hybrid Cat-fish. Agric. J., 1:1-5.

Ajiboye, O.O. and A.F. Yakubu (2010). Some aspects of biology and aquaculture potentials of Tilapia guineensis (Dumeril) in Nigeria. Reviews in Fish Biology and Fisheries, 20:441-455.

Alcazar, E.R.V. (1988). Reversion sexual de Oreochromis niloticus mediante el androgeno mesterolona en pequenosestanques de concreto. In: Simpósio Brasileiro De Aquicultura, 5, Florianópolis. Anais... Florianópolis, UFSC, p. 403-407.

Al-Hakim N.F.A.; M. Saleh; A.Z. Hegazi; A. Ibrahim and K. Aly (2012). Induction of mono-sex (male tilapia) population by inter-specific hybridization and hormonal sex reversal of Nile tilapia. Egypt $\mathbf{J}$ Aquat Biol and Fish, 1:23-33.

Bwanika, G.N.; D.J. Murie and L.J. Chapman (2007). Comparative age and growth of Nile tilapia (Oreochromis niloticus L.) in lakes Nabugabo and Wamala, Uganda. Hydrobiologia, 589:287-301.

Carberry, J.E. and F. Hanley (1997). Commercial intensive tilapia culture in Jamaica. In: Simposio Centroamericano De Aquacultura - Cultivo Sostenible De Camarony Tilapia, 4, 1997, Tegucigalpa, Anais... Honduras: World Aquaculture Society, p. 64-67.

Celik, I.; Y. Guner and P. Celik (2011). Effect of orally-administered $17 \alpha$ methyltestosterone at different doses on the sex reversal of the Nile tilapia (Oreochromis niloticus, Linneaus 1758). Journal of Animal and Veterinary Advances, 10(7):853-857. 
Charo-Karisa, H.; H. Komen; S. Reynolds; M.A. Rezk; R.W. Ponzoni and H. Bovenhuis (2006). Genetic and environmental factors affecting growth of Nile tilapia (Oreochromis niloticus) juveniles: Modeling spatial correlations between hapas. Aquaculture, 255:586-596.

Duncan, D.B. (1955). Multiple range and multiple F tests. Biometrics 11:1-42.

Effiong, B.N.; A. Sanni and J.O. Fakunle (2009). Effect of partial replacement of fishmeal with duckweed (Lemna paucicostata) meal on the growth performance of Heterobranchus longifilis fingerlings. Report Opin., 1(3):76-81.

El-Sayed, A.M. (2002). Effects of stocking density and feeding levels on growth and feed efficiency of Nile tilapia (Oreochromis niloticusL.) fry. Aquaculture Research, 33(8):621-626.

El-Sayed, A.M. (2006). Tilapia culture. CAB International, Wallingford, UK. 277 pp.

El-Sherif, M.S. and A.M. EL-Feky (2008). Effect of ammonia on Nile Tilapia (O. niloticus) performance and some hematological and histological measures. Eighth International Symposium on Tilapia in Aquaculture. Cairo, Egypt.

Ferdous, Z.; N. Nahar; Md. S. Hossen; K.R. Sumi and Md. M. Ali (20014). Performance of different feeding frequency on growth indices and survival of monosex tilapia, Oreochromis niloticus (Teleostei: Cichlidae) fry. International Journal of Fisheries and Aquatic Studies, 1(5):80-83.

Green, B.W. and D.R. Teichert-Coddington (2000). Human food safety and environmental assessment of the use of 17a-methyltestosterone to produce male tilapia in the United States. Journal of World Aquaculture Society, 31:337-357.

Green, B.W.; K.L. Veverica and M.S. Fitzpatrick (1997). Fry and fingerling production. Dynamics of pond aquaculture. CRC Press, Boca Raton, Florida. pp. 215-243.

Guerrero III, R.D. (1975). Use of androgens for the production of all male Tilapia aurea (Steindachner). Transactions of the American Fisheries Society, 104:342-348.

Guerrero, R.D. and W.L. Shelton (1974). An acetocarmine squash method for sexing juvenile fishes. Prog. Fish-Cult., 36: 56.

Lim, C. (1997). Nutrition and feeding of tilapias. In: Simposio Centroamericano De Aquacultura Cultivo Sostenible De Camarony Tilapia, 4, 1997, Tegucigalpa, Anais... Honduras: World Aquaculture Society, p. 94-107.

Luthada, R.W. and H.L. Jerling (2013). Effect of feeding frequency and feeding rate on growth of Oreochromis mossambicus (Teleostei: Cichlidae) fry. African Journal of Aquatic Science, 38(3):273278.

Magid, A. and M.M. Babiker (1975). Oxygen consumption and respiratory behaviour of three Nile fishes. Hydrobiologia, 46:359-367.

Manosroi, J.; K. Petchjul and A. Manosroi (2004). Effect of fluoxymesterone fish feed granule on sex reversal of the hybrid, Thai red Tilapia (Oreochromis mossambicus Linn.). Asian Fisheries Science 17: $323-331$.

Meer, M.B.; H. Herwaarden and M.C.J. Verdegem (1997). Effect of number of meals and frequency of feeding on voluntary feed intake of Colossoma macropomum (Cuvier). Aquac. Res., 28(6):419-432.

Mensah E.T.D.; F.K. Attipoe and M. Asub-Johnson (2013). Effect of different stocking densities on growth performance and profitability of Oreochromis niloticus fry reared in hapa-in-pond system. International Journal of Fisheries and Aquaculture, 5:204-209.

Nwanna L.C. (2003). Risk management in aquaculture by controlled feeding regimen. Pak. J. Nutr., 2(6):324-328.

Pandian, T.J. and K. Varadaraj (1987). Techniques to regulate sex ratio and breeding in tilapia. Current Science, 56:337-343.

Phelps, R.P.; G. Conterras Salazar; V. Abe and B.J. Argue (1995). Sex reversal and nursery growth of Nile tilapia, Oreochromis niloticus (L.) freeswimming in earthen ponds. Aquaculture Research, 26:293-295. 
Phelps, R.P. and T.J. Popma (2000). Sex reversal of tilapia. Pages 34-59 in B.A. Costa-Pierce and J.E. Rakocy, eds. Tilapia Aquaculture in the Americas, Vol. 2. The World Aquaculture Society, Baton Rouge, Louisiana, United States.

Popma, T.J. and B.W. Green (1990). Aquaculture production manual: sex reversal of tilapia in earthen ponds. Research and Development Series No. 35. International Center for Aquaculture, Alabama Agricultural Experiment Station, Auburn University, AL, USA.

Pouomogne, V. and D. Ombredane (2001). Effect of feeding frequency on the growth of tilapia (Oreochromis niloticus) in earthen ponds. Tropicultura, 19 (3):147-150.

Riche, M. and D. Girling (2003). Feeding Tilapia in Intensive Recirculating Systems. North Central Regional Aquaculture Center. 114.

Riche, M.; M. Oetker; D.I. Haley; T. Smithand and D.L. Garling (2004). Effect of feeding frequency on consumption, growth, and efficiency in juvenile tilapia (Oreochromis niloticus). The Israeli Journal of Aquaculture-Bamidgeh, 56(4):247-255.

Rizkalla, E.H.; H.H. Haleem; A.M.M. Abdel-Halimand R.H. Youssef (2004). Evaluation of using $17 \alpha-$ methyl testosterone for monosex Oreochromis niloticus fry production. J. Egypt. Ger. Soc. Zool., 43A:315-335.

Ross, L.G. (2000). Environmental physiology and energetics. pp. 89-128. In: M. C. M. Beveridge and B. J. McAndrew (eds.) Tilapias: Biology and Exploitation, Fish and Fisheries Series 25, Kluwer Academic Publishers, Dordrecht, the Netherlands.

Sanches, L.E.F and C. Hayashi (2001). Effect of feeding frequency on Nile tilapia, Oreochromis niloticus (L.) fries performance during sex reversal in hapas. Acta Scientiarum Animal Science, 23 (4):871876.

Santiago, C.B.; M.B. Aldaba and O.S. ReyesInfluence (1987). Influence of feeding rate and diet form on growth and survival of Nile tilapia (Oreochromis niloticus) fry. Aquaculture, 64 (4):277-282.

Sena S.D. and A.A. Trevor (1995). Fish Nutrition Aquaculture. St Edmundsbury Press, Suffolk, Great Britain.

Shell, E.W. (1996). Proceedings of the FAO world symposium on warm-water pond fish culture. FAO Fisheries Reports No.44, Vol.3.

Siraj, S.S.; Z. Kamaruddin; M.K.A. Satar and M.S. Kamarudin (1988). Effects of feeding frequency on growth, food conversion and survival of red tilapia (O. mossambicus x O. niloticus) hybrid fry. pp. 383-386. In: R.S.V. Pullin, T. Bhukaswan, K. Tonguthai, J.L. Maclean (eds.). 2nd Int. Symp. Tilapia in Aquaculture. ICLARM, Manila, Philippines.

SPSS (2007). Statistical Package For Social Science (for Windows). Release 16 Copyright (C), SPSS Inc., Chicago, USA.

Tung, P.H. and S.Y. Shiau (1991). Effects of meal frequency on growth performance of hybrid tilapia, Oreochromis niloricus x 0. aweus fed different carbohydrate diets. Aquaculture, 92:343-350

Vera Cruz, E.M. and G.C. Mair (1994). Conditions for effective androgen sex reversal in Oreochromis niloticus (L.) Aquaculture, 112:137-248.

Wahby, O.M. and S.H. Shalaby (2010). Oral administration of testosterone in fish diet affect sex differentiation and testis development in tilapia. Research Journal of Agriculture and Biological Sciences 6 (6): 946-952.

Winnie, L.R. (2012). Effect of dietary protein level, feeding frequency and amount of food offered on growth and gastric evacuation of Oreochromis mossambicus fry. M.Sc. Department of Zoology, University of Zululand. 
تأثير معلى التظذية وعدد مراتها على مظاهر النمو ونسبة التحول الجنسى والربحية لزريعة البلطى النيلى في

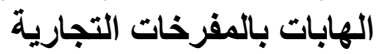

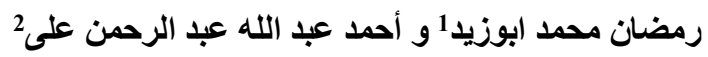

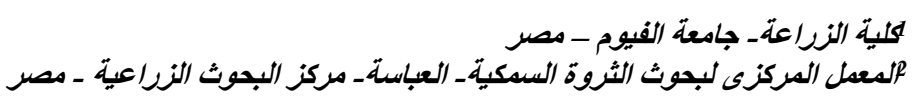

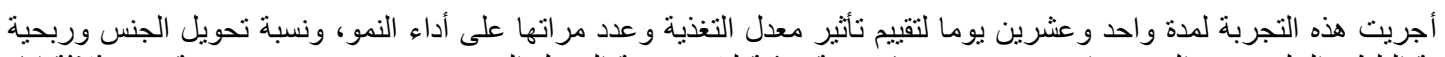

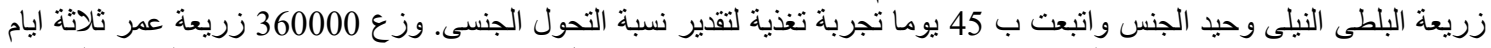

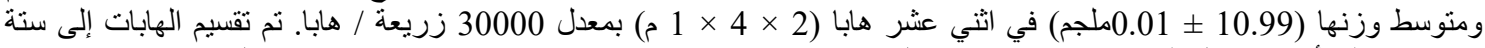

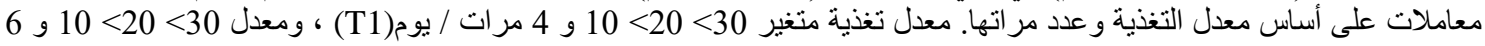

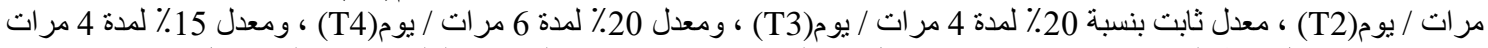

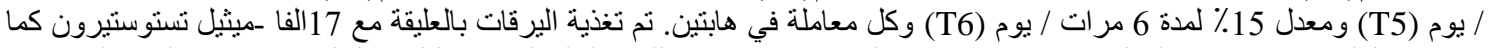

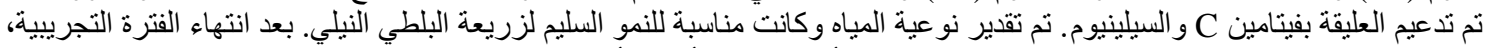

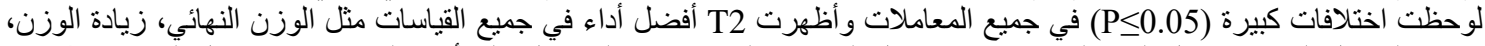

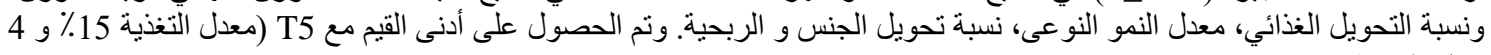
مرات / يوم). 